УДК 621.565:536.58

\title{
Study of floating condensing for energy saving on refrigeration plants in tropical areas
}

\author{
Ph. D. T. C. GUIDI, guidi65@mail.ru \\ University Institute of Technology Lokossa, Benin \\ Ph. D. V. CHEGNIMONHAN, victorin.chegnimonhan@gmail.com \\ University of Nantes (France) \\ $P h . D$. G. C. SEMASSOU, seclar2001@yahoo.fr \\ University of Abomey-Calavi, Benin \\ D. Sc. L. V. GALIMOVA, galimova_lv@mail.ru \\ Astrakhan State Technical University, Russia \\ Ph.D.G.DEGAN, ger_degan@yahoo.fr \\ University of Abomey-Calavi, Benin
}

\begin{abstract}
The research concerns energy saving issues at refrigeration plants in warm tropical areas. The object is to optimize operating cost of the cold stores for food industries by calculating the energy consumption of refrigeration systems for different outside temperatures. The compressor energy consumption decreases as compression ratio becomes low for colder outside temperatures. The determined energy consumption of the fans shows a very small increase when outdoor temperature increases, thus it can be considered to be constant. The floating HP operating mode shows a better COP than the fixed HP one. The calculation for several refrigerants i.e. R717, R404A and R22 having been made, the results show that the COP is better for ammonia than for $R 22$ and $R 404 A$. The annual energy gain is at least $600 \mathrm{kWh} / \mathrm{kW}$ of cooling capacity compared to the fixed HP operating mode. In terms of energy consumption the refrigerant R404A gives the best gain (17\%), and ammonia does $13 \%$. Although temperature does not change a lot over the year in the humid tropical areas concerned, $15 \%$ energy saving can be predicted with floating condensation pressure control. For industrial refrigerating plant, the method appears to be very promising and competitive in terms of energy saving, with investment being very small. It can also permit the design and the management of more environmentally sustainable industrial refrigeration plants.
\end{abstract}

Keywords: energy saving, floating condensing, environment, refrigeration.

\section{Информация о статье}

Поступила в редакцию 05.11.2015, принята к печати 29.01.2016

doi: $10.21047 / 1606-4313-2016-16-1-36-40$

Ссылка для цитирования

Guidi T. C., Chegnimonhan V., Semassou G. C., Galimova L. V., Degan G. Study of floating condensing for energy saving on refrigeration plants in tropical areas // Вестник Международной академии холода. 2016. № 1. С. 36-40.

\section{Исследование плавающей конденсации по энергосбережению}

\section{на холодильных установках в тропических районах}

Канд. техн. наук Т. К. ГУИДИ, канд. техн. наук В. ЩЕГНИМОНХАН,

канд. техн. наук Г. К. СЕМАСУ, д-р техн. наук Л. В. ГАЛИМОВА, канд. техн. наук Ж. ДЕГАН

Настоящее исследование посвящено энергосберегающим решениям в холодильных системах, работающих в условиях жсарких тропиков. Цель заключается в оптимизации операционных расходов холодного хранения для пищевой промышленности, исследуя потребление энергии в системах охлаждения для различных вариаций температуры наружного воздуха. Потребление энергии компрессоров уменьшается, когда коэффициент сжатия снижется при холодных наружных температурах. Расчетное потребление энергии для вентиляторов увеличивается очень незначительно с подъемом наружной температуры, поэтому, его можно считать постоянным. Режим работы с плавающим давлением конденсации показывает лучшее значение потребления энергии на единицу холодопроизводительности, чем режим с фиксированным давлением. Результаты реализации алгоритма для различных хладагентов (R717, R404A и R22) показывают, что величины энергопотребления является лучшими в случае использования аммиака по сравнению с хладагентами $R 22$ и $R 404 A$. Годовое энергосбережение составляет, по меньшей мере, 600 кBmч/кBm хладопроизводительности. С этой точки зрения хладагент R404A имеет лучиий коэффициент (17\%), а аммиак - $13 \%$. Хотя температура не меняется значительно в течение года в тропических районах, $15 \%$ экономия энергии может быть предсказана при использовании регулятора плавающего давления конденсации. Для промышленных холодильных установок этот метод представляется весьма перспективным с точки зрения экономии энергии и конкурентоспособности при очень низких затратах. Он также может способствовать созданию более экологически сбалансированных холодильных установок.

Ключевые слова: энергосбережение, плавающие НР, охраны окружающей среды, охлаждение. 


\section{Introduction}

With the increase of the world population, nutritional needs naturally rise. Thus, various methods are used for the conservation of food in order to reduce food waste. Among those technologies, preservation by cold is one of the most effective one, since other methods such as salting, smoking and cooking can deeply modify the characteristics of the food. Refrigeration better preserves the original qualities of foodstuffs. But this induces a high cost: refrigeration industry is a large electrical energy consumer. According to a report, it represents almost $15 \%$ of the world power consumption [1]. Moreover the electrical consumption of all the cold positions represent 30 to $50 \%$ of the power consumption of a supermarket [2]. It's reported that supermarkets are the largest energy users in the commercial sectors. Thus, commercial and industrial refrigerations are also responsible for considerable Green House Gas emissions [3, 4]. According to [5], supermarkets and superstores in the UK are responsible for 3\% of total energy consumption and $1 \%$ of total GHG emissions. It's worthy noticing that a large part of the energy supply is associated to refrigeration and lighting. There, the consumption due to refrigeration is evaluated between $30 \%$ and $60 \%$ of the total electricity used, but Heating Ventilation and Air Conditioning accounts for $25 \%$. Worldwide, $60 \%$ of the food cross the cold during their life cycles. In the context of France this accounts for 34 million tons of food annually processed by refrigeration [6], and $10 \%$ of the national electricity consumption is for cold applications in agribusiness. Moreover, for a plant, the power requirement for refrigeration represents 40 to $80 \%$ of the activity. The cooling capacities installed in the sector of industrial refrigeration can be of the order of the Megawatt, the equivalence of $10000 \mathrm{MWh}$ or more for a year. So the agri-food industries have such energy expenditure that an increase in the cost of electricity or gas, has a direct impact on their performances and can even engage their economic sustainability [7].

However in recent years, the problems of climate change added to the increased of energy prices due to the depletion of fossil resources, change the attitudes towards energy expenses, particularly in the area of industrial refrigeration. Manufacturers want to limit their expenditures, including those on energy. In line with hat idea, the client will choose primarily

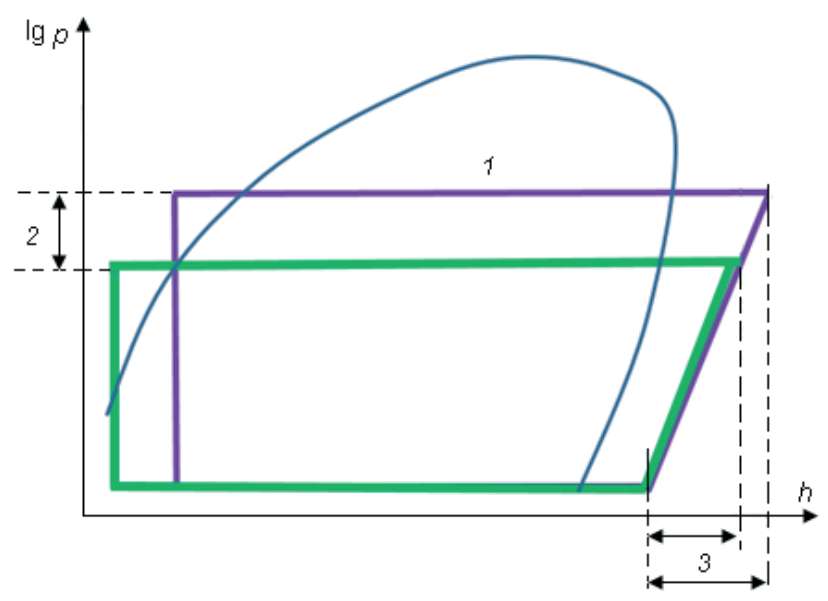

Figure1. Scheme of fixed and floating High Pressure: 1 - Fixed $H P ; 2$ - Floating HP; 3 - compression works an installation with optimized carbon footprint and energy consumption (in $\mathrm{kWh} / \mathrm{m}^{2} /$ year) because the cost of energy is today, and again more tomorrow, a major component [8].

In African tropical areas cold chain is not always maintained due to the high cost of energy, the low performance of refrigeration equipments and, unfortunately, the lack of cooling appliances.

Depending on energy resources and the economic level of tropical countries, much care has to be turned to the improvement of efficient refrigeration systems while minimizing their operating cost in order to provide populations with accurate and safe foodstuffs. To achieve this goal any energy saving method on existent facilities has to be considered and developed. Thus, the objective of this work is to study the factors that impact most on the energy consumption of a cold room and to analyse how to act on the latter to improve energy efficiency.

We are particularly interested in the reduction of energy consumption by the so-named floating condensation pressure or variable high pressure (Floating HP) control. The method consists in lowering the condensing refrigerant pressure of the air condenser when the outdoor temperature gets low. The approach proved effective for regions where temperature variation between cold and warm seasons is really important, i.e. in Northern Europe, etc. Therefore much energy saving is possible in winter as the condensation temperature can be considerably reduced: the compression ratio decreases resulting in less energy need for the compression work (figure 1). Chan and Yu confirmed [9], that reducing the condensing temperature improves the chiller efficiency. They also reported that more condenser fans should probably run to enhance heat transfer of the condenser in order to low down the liquefaction temperature.

In winter time, the minimum condensation temperature is generally limited to $20^{\circ} \mathrm{C}$ for technical reasons. Multi orifice or, to a certain extent, electrical expansion valves are revealed suitable for accurate control.

However, these considerations are not entirely applicable for tropical areas because outside temperature variations are weak all along the year (there is no winter). The literature does not communicate about the feasibility of energy saving in hot tropical countries by modulating the HP according to the weather.

Table 1

\section{Decade report on outside temperatures} and sunshine duration

\begin{tabular}{|c|c|c|c|}
\hline Monts & $\begin{array}{c}\text { Min temperature, } \\
{ }^{\circ} \mathrm{C}\end{array}$ & $\begin{array}{c}\text { Max } \\
\text { temperature, }{ }^{\circ} \mathrm{C}\end{array}$ & $\begin{array}{c}\text { Times } \\
\text { of sunshine, } \mathrm{h}\end{array}$ \\
\hline Januay & 24 & 31 & 214 \\
\hline February & 25 & 32 & 210 \\
\hline March & 26 & 32 & 223 \\
\hline April & 26 & 32 & 219 \\
\hline May & 25 & 31 & 214 \\
\hline June & 24 & 29 & 141 \\
\hline July & 24 & 28 & 136 \\
\hline August & 23 & 28 & 149 \\
\hline September & 24 & 28 & 165 \\
\hline October & 24 & 30 & 208 \\
\hline November & 24 & 31 & 243 \\
\hline December & 24 & 31 & 223 \\
\hline
\end{tabular}


A typical temperature variation is shown on table1. The report is the result of a recent decade observations of the weather. The shape appears almost regular in the year with two singularities for each month: a minimal temperature corresponding to mornings and nights and the maximum temperature is the one that appears with sunshine. The monthly sunshine time is also mentioned on the table.

The mean temperature variation is about $6{ }^{\circ} \mathrm{C}$ and is met almost every day in the year. As nights and mornings are less warm, condensation pressure can be lowered to enhance performances.

\section{Description of the method}

\section{Overview of floating HP}

The energy bill that is inherent in the operation of cooling appliances, far from being negligible, can be lowered (25\% gain is expectable in European countries [10]) by droping the high pressure when outdoor conditions are favourable, with potentially significant gains in winter and in mid-season. Instead of maintaining year-round temperatures of condensation from 40 to $42{ }^{\circ} \mathrm{C}$, corresponding to summer operation type (or «fixed» condensation pressure control), those temperatures can be set from 25 to $28^{\circ} \mathrm{C}$ a large part of the year.

The implementation of floating HP brings several advantages:

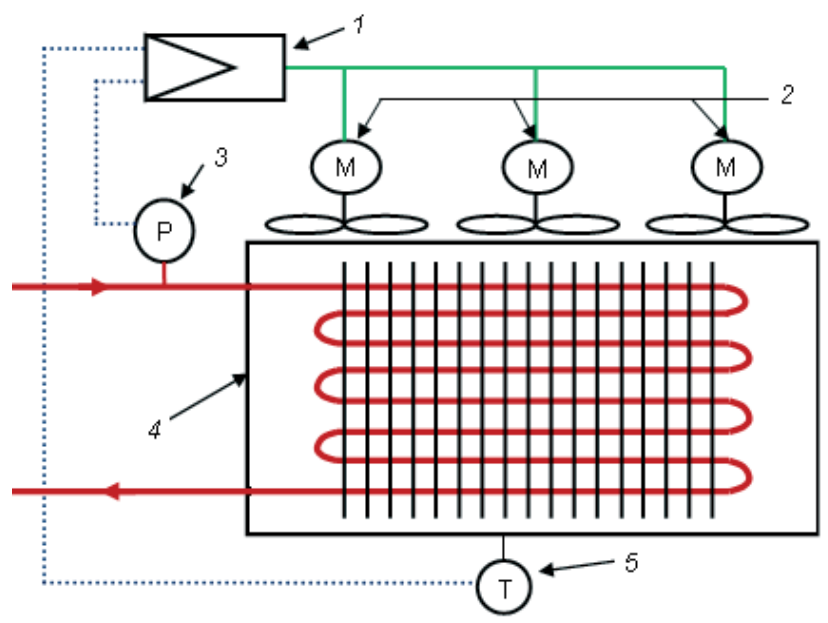

Figure 2: Principles of floating HP control: 1 -Controller; 2 -fan motors; 3 - pressure sensor; 4 - air cooled-condenser; 5 - temperature sensor

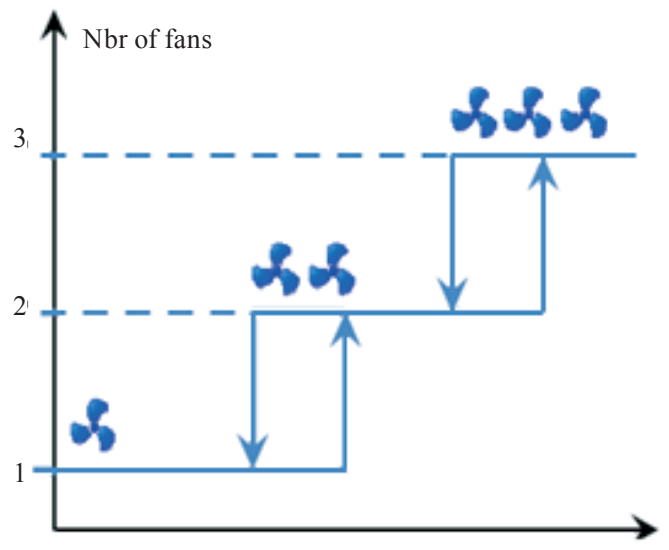

Figure 3. Control of HP (air condenser)
— increased refrigeration capacity, while compressors need less energy.

- The improvement of the lifetime of facilities: compressors operate under relatively smaller compression ratio.

- A decrease of the power released on the condenser; linked to the variation of speed, it allows to limit the number of starts of the motors and to save on the consumption of the fans.

- Less clogging of the condenser.

- The velocity variation and floating HP may be eligible to ECE (energy saving certificates) in France, an official financial grant attributed to support the improvement of environmentally efficient equipments.

The implementation of floating HP is simple and cheap. It just needs a controller, an external temperature sensor, a high pressure sensor, some pressure switches or speed variators. A scheme of the mounting is displayed on figure 2. Technically, on an air condenser, the control of HP results in the initiation in cascade (staged control) of the condenser fans, as shown in the graph 3. However, in the industrial refrigeration, air cooled condensers are little used for the benefit of evaporative condensers due to their high power. Even in that case, the control is also a cascade, but it's the spray pump that makes the first stage (till 50\%). The performance from 50 to $100 \%$ is achieved then by the fan via a speed variator (figure 4).

\section{Implementation of floating condensation in tropi- cal countries}

Air cooled condenser are controlled according to two principles:

- Fixed high pressure control (to maintain a large value of pressure difference between upstream and downstream sections of the expansion valve for a good filling of the evaporators with refrigerant); but the huge energy consumption of compressors even in cold weathers is a penalty.

- Another more interesting alternative is the floating HP. The purpose is to set the HP as low as technologically possible according to the weather. A well proven value for this can be:

$T_{k}=T_{\text {outside }}+10 \mathrm{~K}$, with $\left(T_{k}>20^{\circ} \mathrm{C}\right.$ to permit technologically a good 'feeding' of the evaporators, according to the law):

$$
Q_{v}=K_{v} \sqrt{\frac{p_{k}-p_{0}}{\text { density }}}, \text { with } p_{k}=f\left(T_{K}\right) \text { and } p_{0}=f\left(T_{0}\right)
$$

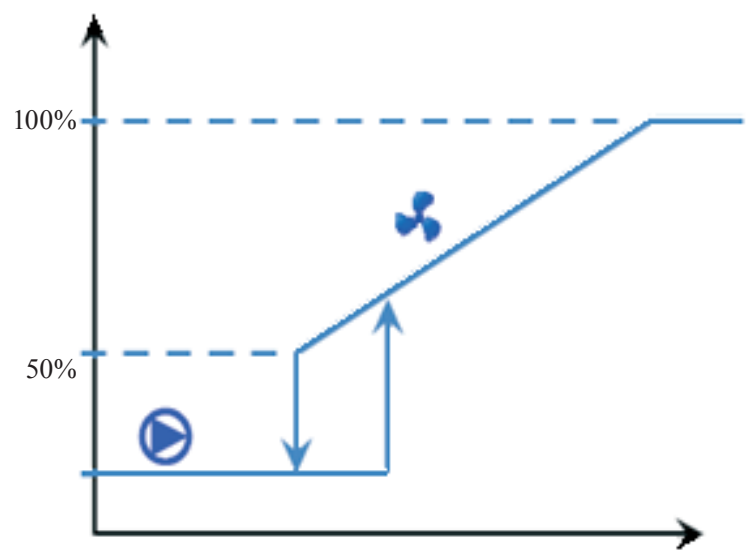

Figure 4. Control of HP (evaporative) condensair) condenser) 
The lower limit $20^{\circ} \mathrm{C}$ for $T_{K}$ makes sure a correct operating of the system even for colder climate. At that limit value, the refrigerant's volume flow through the expansion valve $Q_{v}$ is minimum, but as $T_{K}$ decreases, the trend for the cooling capacity does not decrease.

As the temperature does not vary a lot in the considered site, we made the following assumption: for a given month, $T_{\max }$ corresponds to the temperature when the sun shines (its mean duration has been measured and published by the local meteorological station), otherwise $T=T_{\min }$. Thus, the control of the high pressure can be considered, for a first evaluation, as a switch from $\mathrm{HP}_{\max }$ (sunshine) to $\mathrm{HP}_{\min }$ (no sunshine) as following:

$$
\left\{\begin{array}{l}
\text { if } T_{\text {outside }} \leq \frac{T_{\text {min }}+T_{\text {max }}}{2} \text {, then } \mathrm{HP}=p_{v}\left(T_{k \text { min }}\right)=\mathrm{HP}_{\text {min }}, \\
\text { else } \mathrm{HP}=p_{v}\left(T_{\text {max }}\right)=\mathrm{HP}_{\text {max }} .
\end{array}\right.
$$

The cooling capacity is set to the unit value $1 \mathrm{~kW}$. We did not feel the need to choose a large number even if we were dealing with industrial or tertiary plants. The point was to examine the feasibility of the concept and the behaviour of parameters (COP, energy consumption for the unit cooling capacity)

The algorithm of the calculations is presented on figure 5. We made further assumptions as:

- Evaporation temperature: - $18{ }^{\circ} \mathrm{C}$ (being constant);

- Useful superheat $=5 \mathrm{~K}$ and total superheat $=10 \mathrm{~K}$;

- No pressure loss;

- Investigated refrigerants: R22 (still allowed in maintenance of equipments in Sub-Saharan Africa), ammonia (R717) and R404A;

- Reciprocating compressors and air cooled condensers;

- The total energy consumption is the addition of the consumptions of compressors and fans.

\section{Results and discussion}

The annual variation of the liquefaction temperature shows an average value of $34^{\circ} \mathrm{C}$ for $T_{k \min }$ with a standard value of $2{ }^{\circ} \mathrm{C}$, and $40.3{ }^{\circ} \mathrm{C} \pm 2{ }^{\circ} \mathrm{C}$ for $T_{k \max }$ (figure 4 ).

Converted into saturated vapour pressure, values vary according to the nature of refrigerants (R717, R404A, R22). On the graph, for each month, the long bar corresponds to the temperature when sun shines. The gain in energy is noticeable when the high pressure is reduced to $\mathrm{HP}_{\text {min }}$ according to outdoor temperature (figure 6). The longer bars are as-

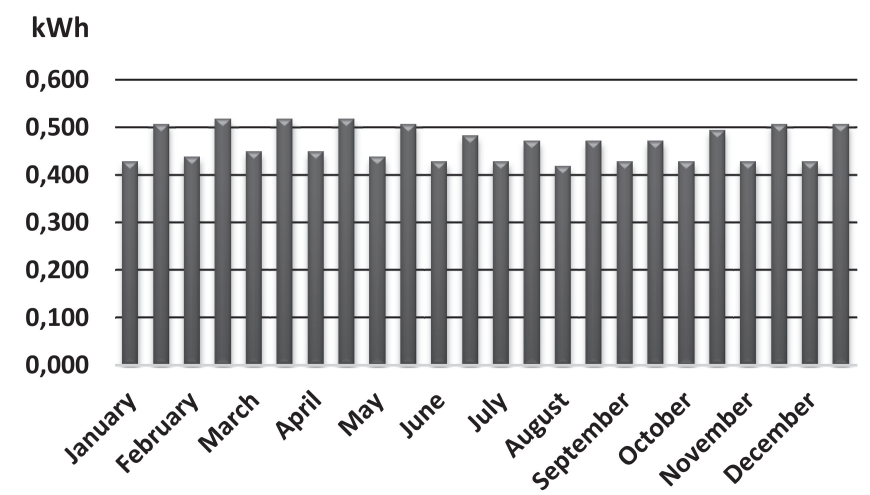

Figure 7. Energy gain with floating HP (with R404A)

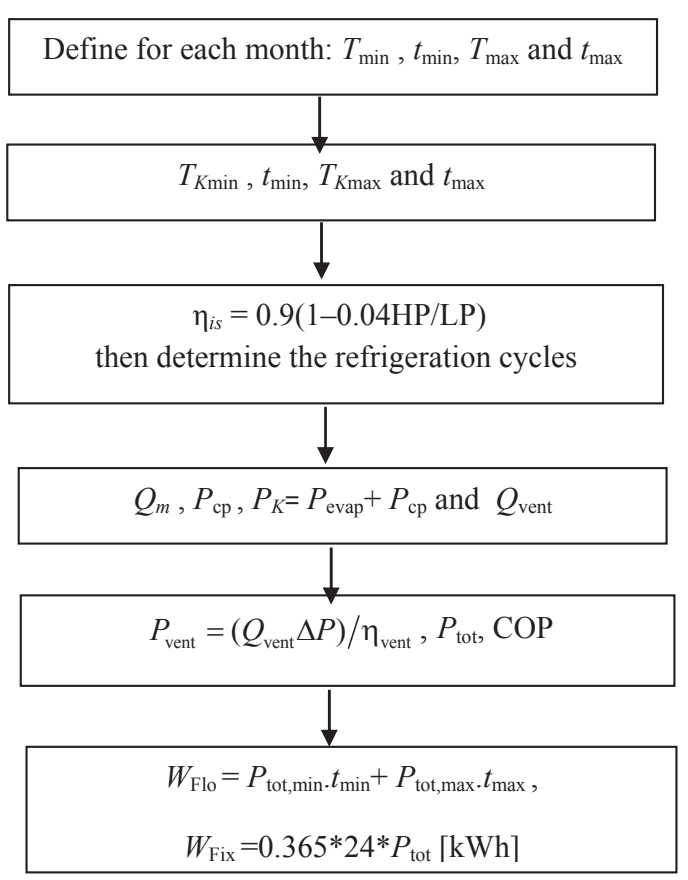

Figure 5. Algorithm of calculation

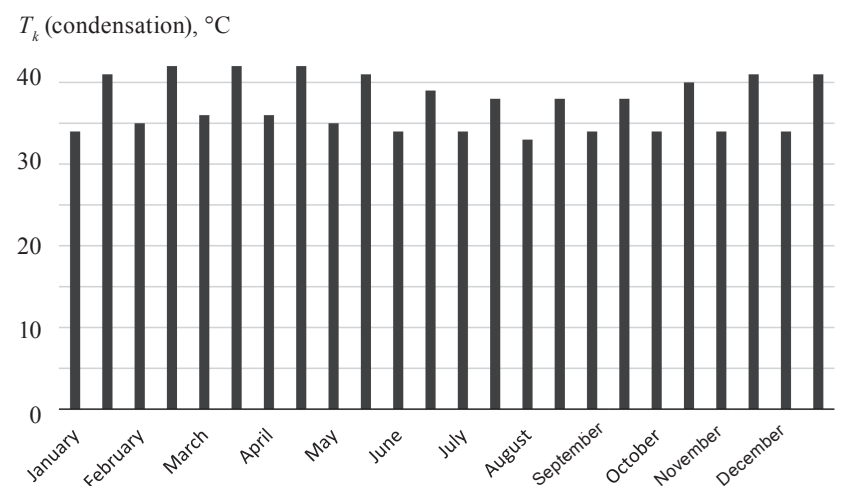

Figure 6. Variation of $T_{k \min }$ and $T_{\text {kmax }}$ over the year

sociated with $\mathrm{HP}_{\max }$. The phenomenon is recurrent all along the year (figure 7), although duration of $\mathrm{HP}_{\max }$, i.e. sunshine time is smaller than the occurrence of $\mathrm{HP}_{\text {min }}$ (night and early in the morning, or with cloudy weather).

The power consumption of compressors increases with the outside temperature, $P_{\text {fans }}$ changes very slightly (figure 8 ). This feature strengthens the usefulness and the validity of the method.

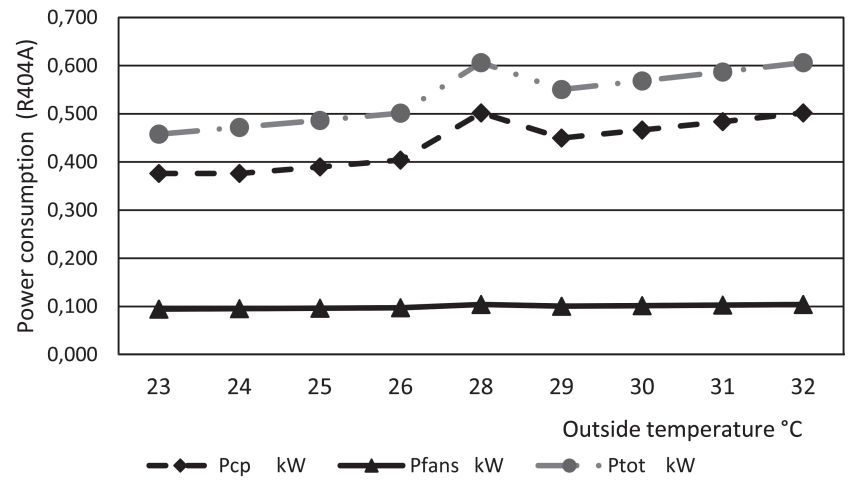

Figure 8. Evolution of powers vs. $T_{\text {outside }}$ 


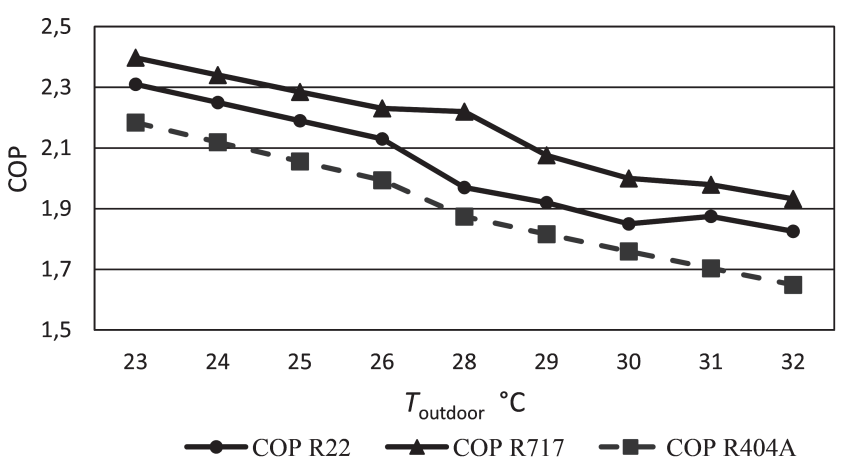

Figure 9. Influence of the nature of fluids on performances with floating HP

Table 2

Energy consumptions and economic comparisons

\begin{tabular}{|l|c|c|c|}
\hline \multicolumn{1}{|c|}{ Parameters } & R22 & R717 & R404A \\
\hline $\begin{array}{l}\text { Annual consumption with floating } \\
\text { HP (kWh) }\end{array}$ & 4110 & 3938 & 4420 \\
\hline $\begin{array}{l}\text { Annual consumption with fixed HP } \\
\text { (kWh) }\end{array}$ & 4794 & 4534 & 5312 \\
\hline Gain in kWh & 689 & 595 & 892 \\
\hline Gain \% & 14 & 13 & 17 \\
\hline Gross profit XOF & 137800 & 119200 & 178400 \\
\hline
\end{tabular}

The COP of the refrigeration plant has been performed for several refrigerants taking into account HP control as aforementioned. For the three fluids investigated the coefficients of performance vary between 1.65 and 2.34 (figure 9). Ammonia achieved the best score, followed by the HCFC R22, even if out of date today for new equipments. The COP decreases as outside temperature raises up, as predicted.

Comparisons are made between the fixed HP operating and the modulate HP one (all over the year). The results are summarized on table 2 . Obviously performances are better with floating HP. The annual energy consumption is lower for ammonia. But the intrinsic energy gain is better for the HFC R404A. The results, as expected, are not as good as it can be in colder countries. However, a mean energy saving of $15 \%$ is expectable. It's an interesting perspective for industrial refrigeration plants. The estimated cost of the implementation of floating HP by unit cooling power $(1 \mathrm{~kW})$ is evaluated to $250 \mathrm{kXOF}$. Thus, the return time for the investment can be less than 2 years.

\section{Conclusion}

In the current economic and environmental context, energy saving solutions are becoming increasingly popular. Throughout this study, it appears clearly that the floating HP is an effective technique even in warm, humid African countries, and this all along the year.

The cost relating to the implementation of this method varies, of course, according to the size of the installations. However, very significant energy saving can be made with the approach $(-15 \%)$. This is a solution with a good return on investment for refrigeration plants, even in Africa. A proper focus and a good management of floating condensation control help to achieve a good continuity in the cold chain, to limit food waste and thus provide a good alternative to the problem of food insecurity. Moreover the method contributes to the reduction of the environmental footprint of equipments.

\section{Subscripts:}

$\mathrm{cp}$ - compressor; $\mathrm{m}$ - mass; evap — evaporator; min — minimum; is — isentropic; max - maximum; Fix — fixed; 0 - for Low pressure; Flo — floating; $\mathrm{v}$ - volume, vapour, or valve; $\mathrm{k}$ — condenser; vent fan.

\section{Nomenclature}

\begin{tabular}{|c|c|c|}
\hline Symbols & Units & Denominations \\
\hline$h$ & ${\mathrm{~kJ} . \mathrm{kg}^{-1}}^{-1}$ & Specific enthalpy \\
\hline$Q$ & $\mathrm{~m}^{3} \mathrm{~s}^{-1}$ or $\mathrm{kgs}^{-1}$ & (Volume or mass) flow \\
\hline$p$ & Bar or Pa & Pressure \\
\hline$P$ & W or kW & Power \\
\hline$t$ & $\mathrm{~s}$ & Time \\
\hline$T$ & ${ }^{\circ} \mathrm{C}$ & Temperature \\
\hline$W$ & $\mathrm{kWh}$ & Energy consumption \\
\hline $\mathrm{XOF}$ & franc & West African money \\
\hline$\eta$ & - & efficiency \\
\hline
\end{tabular}

\section{References}

1. Chégnimonhan, V., Josset C., Peerhossaini, H. (2010). Ice slurry crystallization based on kinetic phase-change modeling. International Journal of Refrigeration, pp. 1-10.

2. Thélia. (2010). Pourquoi installer une HP flottante, Douai.

3. Bagarella, G., Lazzarin, R., \& Noro, M. (2014). Annual Energy analysis of a water loop self-contained refrigeration and comparison with multiplex systems in supermarket. International Journal of refrigeration, 55-63.

4. Meunier, F., Rivet, P., Terrier, M.-F. Froid industriel, 2eme édition DUNOD 2010, pp. 493.

5. Tassou, S. A., Hadawey, Y., Ge. Marriott, D. August (2010). Energy Consumption and Conservation in food retailing. Applied Thermal Engineering, pp. 147-156.

6. ADEME, Rapport efficacité énergétique, 2010.

7. Favereau, M., Développement d'une gamme de thermofrigopompes, Mémoire ITII, Université de Nantes, 2010.

8. Wilson S. L'avenir des métiers du froid en 2020-2025, Revue Pratique du Froid, RPF1000, nov. 2011, p. 20-23.

9. Chan, K. T., Yu, F. W. Analysis of the component characteristics of air-cooled chillers for modelling floating condensing temperature control. Energy Conversion and management 46 (2005) 927-939.

10. Carel, (2006). HP et BP flottante. Paris: rci 1.1. 